УДК 582.579.2:615.32

\title{
КИПРЕЙ УЗКОЛИСТНЫЙ (CHAMERION ANGUSTIFOLIUM L.) ХИМИЧЕСКИЙ СОСТАВ, БИОЛОГИЧЕСКАЯ АКТИВНОСТЬ (ОБЗОР)
}

\author{
(C) В.Н. Царёв ${ }^{1,2 *}$, Н.Г. Базарнова ${ }^{I}$, М.М. Дубенский ${ }^{I}$ \\ ${ }^{1}$ Алтайский государственный университет, пр. Ленина, 61, Барнаул, 656049 \\ (Россия), e-mail: tsarewvn@gmail.com \\ ${ }^{2} \mathrm{OOO} \mathrm{«Лаборатория} \mathrm{гринап»,} \mathrm{ул.} \mathrm{Крупской,} \mathrm{145,} \mathrm{Барнаул,} 656031$ (Россия)
}

В обзоре рассматривается растение кипрей узколистный семейства кипрейные (Chamerion Angustifolium Onagraceae), места его естественного произрастания, ботаническое и морфологическое описание, фармакологические свойства и химический состав.

Химический состав кипрея узколистного достаточно подробно изучен - как элементный, так и компонентный, но, несмотря на это, до настоящего времени не выявлена взаимосвязь биологически активных комплексов с фармакологическим действием, не разработано ни одного проекта ФС, не создано ни одного лекарственного средства с комплексом биологически-активных веществ, извлеченных из кипрея узколистного.

Существуют предположения о механизме противоопухолевого действия кипрея узколистного и мелкоцветного, но нет установленной зависимости химического состава от действия.

Данные обзора служат обоснованием для дальнейшего изучения химического состава кипрея узколистного, с целью установить взаимосвязь химического состава и его действия как онкопротектора. Ставится также цель разработать методику экстрагирования сухого и свежего сырья (травы кипрея узколистного) с максимальной биологической активностью.

Ключевые слова: кипрей узколистный (Chamerion Angustifolium Onagraceae), экстрактивные вещества, химический состав, биологическая активность, способы извлечения.

Морфологическое описание и распространение кипрея узколистного (Chamerion Angustifolium).

Кипрей узколистный (в народе иван-чай), это многолетнее травянистое растение семейства кипрейные, все семейство включает в себя порядка 22-24 родов и боле 640 видов $[1,2]$. На территории России широко распространены шесть родов, включающих примерно 70 видов [3-5].

Распространение. Кипрей узколистный широко распространен практически по всей территории России и европейской части бывшего СССР $[6,7]$. Хорошо растет в светлых лесах, на вырубках, в сухих песчанистых местах, вдоль железнодорожных насыпей, возле посевов [1, 6], на осушенных болотах [8] и обочинах дорог $[8,9]$. Предпочитает селиться в таких местах, где отсутствует плодородный слой, а почва имеет сильную минерализацию (после лесных или торфяных пожаров) [8-10]. Отличается высокой чувствительностью к нефтезагрязнению [11].

Размножение. Семена кипрея узколистного - очень мелкая семянка, прикрепленная к пушинкепарашюту. На растении вызревает порядка 10-30 тыс. семян, радиус разлета которых достигает 100 км.

\footnotetext{
Царёв Виталий Николаевич - директор по развитию

ООО «Лаборатория гринап», аспирант кафедры органической химии, АлтГУ,

e-mail: tsarewvn@gmail.com

Базарнова Наталья Григорьевна - доктор химических наук, профессор, заведующая кафедрой органической химии, декан химического факультета, e-mail: bazarnova@chemwood.asu.ru

Дубенский Максим Михайлович - студент третьего курса химического факультета АлтГУ, e-mail: dubenskiy2016@gmail.com
}

Размножение кипрея происходит в большей степени за счет разрастания корневища, а не семенами, при этом в течение 10 лет образуются многокилометровые заросли [12]. Обилие отмерших побегов кипрея на месте его зарослей способствует образованию плодородного слоя почвы, на котором селятся растения других видов и постепенно вытесняют кипрей узколистный. Массового разрастания кипрея узколистного не происходит из-за большой слабости

\footnotetext{
*Автор, с которым следует вести переписку.
} 
сеянцев кипрея, которые не переносят малейшей конкуренции со стороны других видов растений. Главные условия для выращивания кипрея - сильно минерализованная почва, высокая интенсивность солнечного света в течение дня, повышенная влажность воздуха в ночное время $[1,9]$.

В настоящее время материал кипрея узколистного получают методом, микроклонального размножения, который хорошо освоен как в отечественной науке [12], так и за рубежом [13]. Данный метод позволяет получить чистую культуру с определенным составом микроэлементов в достаточно короткое время и в больших количествах $[14,15]$. К несомненным плюсам микроклонального размножения стоит отнести тот факт, что оно не зависит от погодных факторов. Как важный фактор необходимо отметить возможность создания стерильной среды в инкубационных боксах, что гарантирует отсутствие патогенной микрофлоры в субстрате и регенеранте и позволяет в более мягких условиях извлекать биологически активные вещества из регенеранта и максимально сохранить их в нативном состоянии без добавления консервантов [16-18].

Народные названия. В народе кипрей узколистный имеет более двух десятков названий. Например: богородицына трава, сорочьи глаза, дятельник, елушник, дрема, дремуха, боровое зелье, ива трава, и многие другие [19]. Такое разнообразие названий одного растения свидетельствует о том, что его использование носит не локальный, а массовый характер.

Ботаническое описание. Кипрей узколистный имеет толстое ползучее корневище, густо облиственный прямостоячий стебель округлой формы высотой от 0,5 до 1,5 м, корневая система способствует развитию многочисленных почек для обеспечения высокой скорости вегетативного размножения. Строение листа простое, по форме лист линейно-ланцетный, сидячий или с коротким черешком, край листовой пластинки цельный или мелко-железисто-зубчатый, заостренный, к основанию клиновидно суженный. Листовая пластинка темно-зеленая, блестящая сверху, снизу сизо-зеленая, пурпурно-красная, иногда бледно-розовая. Цветки окрашены в пурпурно-розовый цвет [1], соцветие - кисть [1,3] длиной до 0,4 м [6]. Плод - пушистая, немного изогнутая коробочка, напоминающая стручок. Семена голые, продолговатые, наверху с длинными тонкими белыми волосками [3].

Химический состав. Биомасса кипрея узколистного имеет достаточно богатый элементный состав. В наземной части установлено наличие 61 элемента: $\mathrm{Na}, \mathrm{Mg}, \mathrm{P}, \mathrm{K}, \mathrm{Ca}, \mathrm{Si}, \mathrm{Br}, \mathrm{Li}, \mathrm{B}, \mathrm{Al}, \mathrm{Ti}, \mathrm{V}, \mathrm{Cr}, \mathrm{Mn}, \mathrm{Co}, \mathrm{Ni}$, $\mathrm{Cu}, \mathrm{Zn}, \mathrm{Ga}, \mathrm{Se}, \mathrm{Rb}, \mathrm{Sr}, \mathrm{Zr}, \mathrm{Mo}, \mathrm{Ag}, \mathrm{Cd}, \mathrm{Sn}, \mathrm{Sb}, \mathrm{I}, \mathrm{Cs}, \mathrm{Ba}, \mathrm{La}, \mathrm{Ce}, \mathrm{Nd}, \mathrm{Au}, \mathrm{Be}, \mathrm{Ge}, \mathrm{As}, \mathrm{Y}, \mathrm{Nb}, \mathrm{Pr}, \mathrm{Sm}$ и др. [20, 21$].$ Накопление элементов зависит от района произрастания растения [22]. При исследовании выявлено, что компонентный состав элементов различных органов растения примерно сравним, однако в листьях больше накапливаются $\mathrm{Na}, \mathrm{Mg}, \mathrm{Si}, \mathrm{Ca}, \mathrm{Cr}, \mathrm{Mn}$, в стеблях - Ni, Ba, в соцветиях - P, K, Cu, Zn, Se, Rb, Ag. Химические элементы в организме растения находятся в связанном виде или в виде катионов и анионов [20].

В биомассе кипрея узколистного обнаружено большое разнообразие биологически активных веществ. Эфирное масло из цветков кипрея узколистного, полученное методом гидродистилляции, содержит: 3 -гексен-1-ол - $15,4 \%$; $\alpha$-пинен $-2,5 \%$; камфен $-0,4 \%$; бензальдегид $-1,6 \%$; $\Delta 3$-карен $-0,6 \%$; лимонен $1,5 \%$; камфару $-0,8 \%$; бензоацетальдегид $-24,3 \%$; терпинеол $-1,7 \%$; линалоол $-10,9 \%$; линалилпропиат $10,9 \%$; эвгенол $-20,2 \%$ [23, 24].

В вегетативной части кипрея узколистного обнаружено 16 аминокислот, шесть из которых незаменимых (в настоящее время принято считать, что для взрослого человека существует восемь незаменимых аминокислот). 100 г сухого сырья кипрея узколистного покрывает от 5 до 10\% суточной потребности для взрослого человека в незаменимых аминокислотах (табл. 1) [25].

Среди 35 липофильных кислот, выделенных путем ступенчатого экстрагирования в проточном перколяторе с помощью метил-трет-бутилового эфира (МТБЭ) [26], найдено повышенное содержание пальмитиновой и линолевой кислот [27-29]. Подобное разнообразие и количество жирных кислот позволяет рассматривать кипрей узколистный как перспективный источник липофильных соединений и дает предпосылки для разработки методов экстрагирования липофильных БАВ как в виде отдельного комплекса, так и в виде смеси липофильной и гидрофильной фракций (табл. 2).

В биомассе листьев содержатся органические кислоты [30-32], таниды [33, 34], антоциановые соединения [33, 35], каротиноиды [31, 32, 36], вещества флавоноидной природы [37-40], аскорбиновая кислота от 25,15 до 49,11 мг\%, содержание которой такое же, как в лимоне (40 мг\%) [41, 42], пектин [31, 33, 43], рутин [30], полисахариды, лигнин [31], кумарины [31, 35, 44], ауроны [30], таннины [9, 32, 34, 45] (в т.ч. ханерол) [46, 47], стеролы, тритерпены [48], простые фенолы и полифенольные соединения [39, 49-

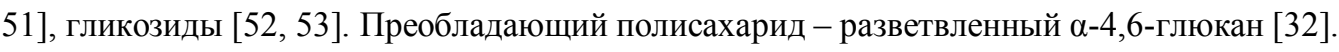


Таблица 1. Содержание свободных аминокислот в вегетативной части кипрея узколистного

\begin{tabular}{l|c|c}
\hline \multicolumn{1}{c|}{ Аминокислота } & $\begin{array}{c}\text { Содержание аминокислоты } \\
\text { (воздушно-сухое сырье), \%. }\end{array}$ & Доля от общего содержания аминокислот, \% \\
\hline Лизин & 0,46 & 4,56 \\
Гистидин & 0,26 & 2,58 \\
Аргинин & 0,58 & 5,75 \\
Аспарагин & 1,29 & 12,78 \\
Треонин & 0,49 & 4,85 \\
Серин & 0,52 & 5,15 \\
Глутамин & 1,77 & 17,54 \\
Пролин & 0,62 & 6,14 \\
Глицин & 0,55 & 5,45 \\
Аланин & 0,6 & 5,95 \\
Валин & 0,61 & 6,05 \\
Метионин & 0,13 & 1,29 \\
Изолейцин & 0,5 & 4,96 \\
Лейцин & 0,82 & 8,13 \\
Тирозин & 0,31 & 3,07 \\
Фенил & 0,58 & 5,75 \\
\hline
\end{tabular}

Таблица 2. Липофильные кислоты экстракта из вегетативных органов кипрея узколистного, массовая доля от веса фракции (\%)

\begin{tabular}{|c|c|c|c|c|}
\hline \multirow{2}{*}{ Кислота } & \multicolumn{2}{|c|}{ Листья } & \multicolumn{2}{|c|}{ Стебли } \\
\hline & свободная & связанная & свободная & связанная \\
\hline Каприновая & 0,12 & 0,36 & 0,10 & 0,11 \\
\hline Лауриновая & 0,23 & 2,09 & 0,18 & 0,72 \\
\hline Миристиновая & 1,59 & 10,40 & 0,54 & 2,77 \\
\hline Пентадекановая & 0,38 & 0,26 & 0,58 & 0,71 \\
\hline Пентадеценовая & 0,10 & 0,22 & 0,16 & 1,72 \\
\hline Пальмитиновая & 15,27 & 23,18 & 27,80 & 25,64 \\
\hline Пальмитолеиновая & 0,36 & 0,51 & 0,40 & 0,72 \\
\hline Маргариновая & 0,20 & 0,44 & 0,84 & 0,75 \\
\hline Стеариновая & 1,73 & 4,50 & 2,98 & 3,47 \\
\hline Олеиновая & - & 0,46 & 1,62 & 1,50 \\
\hline Линолевая & 5,55 & 13,25 & 14,00 & 24,83 \\
\hline Линоленовая & 10,55 & 24,86 & 13,61 & 14,58 \\
\hline Нонадекановая & - & - & 0,30 & 0,45 \\
\hline Арахиновая & 1,71 & 5,75 & 4,02 & 8,94 \\
\hline Генэйкозановая & 0,12 & 0,36 & 0,88 & 0,77 \\
\hline Бегеновая & 1,00 & 1,56 & 1,02 & 2,14 \\
\hline Трикозановая & 0,22 & 0,23 & 0,26 & 0,67 \\
\hline Тетракозановая & 1,61 & 2,03 & 0,62 & 0,82 \\
\hline 2-гидрокси-трикозановая & - & - & - & 0,26 \\
\hline Пентакозановая & 0,10 & 1,20 & 0,18 & 0,51 \\
\hline 2-гидрокситетракозановая & - & 0,31 & - & 0,58 \\
\hline Гексакозановая & 0,86 & 1,71 & 1,64 & 1,31 \\
\hline Гептакозановая & Следы & 0,81 & 0,14 & 0,47 \\
\hline 2-гидроксигексакозановая & - & 0,64 & - & - \\
\hline Октакозановая & 0,58 & 1,82 & 2,88 & 2,02 \\
\hline Нонакозановая & Следы & 0,47 & Следы & 0,34 \\
\hline 2-гидроксиоктакозановая & - & 0,55 & - & - \\
\hline Триаконтановая & 0,17 & 0,96 & 1,62 & 1,25 \\
\hline 2-гидрокситриаконтановая & - & 0,26 & - & - \\
\hline Олеаноновая & 10,00 & - & 2,92 & - \\
\hline Урсоловая & 37,00 & - & 17,60 & - \\
\hline Урсоновая & 1,09 & - & 0,38 & - \\
\hline Олеаноновая & 0,34 & - & 0,38 & - \\
\hline Ацетилурсоловая & 0,18 & - & 0,58 & - \\
\hline Помоловая & 5,36 & - & 7,22 & - \\
\hline
\end{tabular}


Способы экстрагирования биологически активных веществ из сухого сырья кипрея узколистного. Известно несколько традиционных способов извлечения экстрактивных веществ из сухого растительного сырья: водное или неводное экстрагирование, статическое или динамическое. В качестве самостоятельного вида экстрагирования выделяют технологию экстрагирования с помощью сжиженных газов.

Статическое спиртовое экстрагирование проводят следующим образом. Сырье (надземная часть Ch. Angustifolium), измельченное до размера частиц 0,5-3 мм, трехкратно обрабатывают 70\% водным этанолом в соотношении сырье: экстрагент $1:(68-72)$ в течение 30 мин при 80-82 ${ }^{\circ} \mathrm{C}$, с последующим объединением экстрактов, отгонкой этанола, упариванием и сушкой в вакуум-сушильном аппарате. Выход готового продукта составляет $38-40 \%$ от массы воздушно-сухого сырья.

Сухой экстракт кипрея узколистного - это аморфный порошок от желто-коричневого до светлокоричневого цвета со специфическим запахом и вяжущим горьковатым вкусом, хорошо растворимый в 50-70\% водном этаноле, не гигроскопичен, не комкуется [32].

Выход экстрактивных веществ, извлеченных при исчерпывающей экстракции диэтиловым эфиром, этилацетатом, изопропиловым спиртом и водой, составил соответственно: 4,10, 10,06, 22,84, 46,07\% [31].

При экстрагировании соцветий кипрея узколистного диметилформамидом с последующим осаждением ацетатом свинца и обработкой сероводородом, диализом в присутствии $\alpha$-токоферола и трилона Б получают фитогемагглютинин, обладающий противоопухолевой активностью [54].

Как видно из представленных данных, в разное время осуществлялись попытки получения экстракта кипрея узколистного с помощью различных экстрагентов, наиболее распространенным из них является водно-спиртовая смесь, но при ее использовании теряется большая часть БАВ (белковой природы) за счет их выпадения в осадок и денатурации.

Экстрактивные вещества, извлеченные гексаном, проявляют более низкий эффект в качестве онкопротекторов [55].

Наиболее полное извлечение экстрактивных веществ обеспечивается при применении воды в качестве экстрагента. Но для увеличения глубины экстракции, сокращения продолжительности экстрагирования, сохранности БАВ в экстракте следует применять современные динамические методы водного экстрагирования, использование сорастворителей (таких как этанол, монопропиленгликоль и др.) в концентрации до 5\% (данные получены путем экспериментального подтверждения в Алтайском центре контроля качества и сертификации лекарственных средств).

Применение в качестве сорастворителей этанола и монопропиленгликоля в методах водного экстрагирования (как статического, так и динамического) повысит глубину экстракции, не привнося при этом канцерогенных веществ в готовый экстракт.

Экстракция сжиженными газами позволяет получить дифильную фракцию из сырья кипрея узколистного, что априори увеличит его терапевтическую эффективность.

Фармакологическое действие препаратов кипрея узколистного. Кипрей узколистный в России не относится к фармакопейным растениям, несмотря на то, что используется в народной медицине не первое столетие и его химический состав хорошо изучен [6, 14, 41, 56-63].

В народной медицине экстракты из кипрея узколистного применяли:

- в качестве противовоспалительного средства, в частности при воспалении ротовой полости, этот эффект, по-видимому, связан с наличием в его составе дубильных веществ [32, 35, 43];

- при язвенной болезни желудка, гастритах и колитах - экстракты кипрея узколистного обладают обволакивающими свойствами [32,35];

- при заболеваниях в женской половой сфере (достоверных данных о том, какие именно вещества из состава экстрактов оказывают данное воздействие, нет) [9, 64];

- $\quad$ как витаминное средство, из-за высокого содержания витамина С в составе экстрактов $[41,42,58]$;

- $\quad$ в качестве онкопротектора, для профилактики и лечения онкологий органов малого таза (нет данных о точном механизме действия) $[47,65,66]$.

В качестве объекта для изучения фармакологических свойств кипрея узколистного современная наука использует экстракты травы кипрея узколистного, полученные с помощью различных технологий, так как это позволяет многократно усилить фармакологический эффект за счет избавления от балластных веществ. 
На сегодняшний момент существует ряд исследований, показывающих эффективность и безопасность препаратов кипрея узколистного.

Экстракты кипрея узколистного малотоксичны (в них не содержится сильнодействующих и ядовитых веществ), что отмечается как в отечественных [6, 30, 31], так и зарубежных исследованиях [67, 68], которые проводились, начиная с конца 60 -х гг. прошлого века. В результате токсикологических исследований препараты кипрея узколистного были отнесены к 4 классу малотоксичных веществ, летальная доза (ЛД50) настоя кипрея узколистного составляет выше 250 г/кг из расчета на сухое вещество [30].

Препараты кипрея узколистного не обладают генотоксическим действием (т.е. не оказывают мутагенного воздействия на ДНК), что очень актуально в настоящее время в связи с наличием большого количества мутагенных факторов. Подобного рода исследования проводили зарубежные ученые [69], в частности изучалось воздействие препаратов кипрея узколистного на рост придаточных половых органов у крыс [54] и воздействие на организм неомыляемых тритерпеноидов [48].

Антиоксидантные свойства препаратов кипрея узколистного обусловлены его влиянием на интенсивность образования активных форм кислорода, определяемых in vitro хемилюминесцентным методом [70]. Выявлена взаимосвязь полифенолов с антиоксидантными свойствами кипрея узколистного [71-73]. Проводились исследования как in vivo, так и in vitro, ставящие своей задачей оценку антиоксидантного действия в зависимости от химического состава [74]. Авторами [75] предприняты попытки связать противовоспалительное и антиоксидантное действие препаратов кипрея узколистного. Однако достоверно доказать причинно-следственную связь, которая отвечает за антиоксидантный эффект кипрея узколистного, до сих пор не удалось.

Цитопротекторное действие экстрактов кипрея узколистного до конца не изучено и требует уточнения, хотя работы в этом направлении велись как в нашей стране, так и за рубежом. В частности, изучались влияние тритерпеноидов на организм [76] и влияние некоторых флавоноидов на величину окислительного стресса $[38,77]$.

Сосудоукрепляющее действие экстрактов из кипрея узколистного обусловлено наличием в них флавоноидов [78], хотя с полной уверенностью говорить об этом не корректно, так как сосудоукрепляющее действие оказывает большой комплекс экстрактивных веществ [31]. В частности важную роль играет липидный комплекс [27, 71], элементы которого являются составными частями клеточной стенки [29], обеспечивающей эластичность капиллярной стенки $[28,79]$. Высокое содержание витамина С также способствует стабилизации мембраны клеточной стенки $[79,41]$.

Обволакивающее и вяжущее действие кипрея узколистного, по-видимому, обусловлено наличием в его составе дубильных веществ [34, 45], и как следствие - противовоспалительный эффект [75, 81, 82]. Осуществлялись попытки локализации биологически активных веществ, ответственных за противовоспалительное действие кипрея узколистного [83]. В результате проведенных исследований установлен коэффициент противовоспалительного действия $1: 400$ [43], однако данные требуют уточнения.

Жаропонижающее и болеутоляющее действие обусловлено наличием в химическом составе кумаринов [31], хотя оно достаточно слабо выражено и использование кипрея узколистного в этих целях не рационально.

Положительное влияние на скорость общего метаболизма принято относить на счет алкалоидов, содержащихся в кипрее узколистном [84], также им приписывают благотворное воздействие на ЦНС и кровообращение в целом [31].

Противовирусное действие препаратов кипрея узколистного установлено в отношении вируса герпеса, в одном из исследований его связывают с наличием танинов в составе [85].

Противомикробное действие препаратов кипрея узколистного изучалось начиная с 50 -х гг. прошлого века [79], в последующем проводились исследования более глубокого уровня, и была установлена связь полифенольных соединений в составе кипрея узколистного с антимикробным действием на грамположительные и грамотрицательные микроорганизмы $[86,87]$. Однако по силе антимикробного действия кипрей узколистный уступает многим лекарственным растениям $[35,43]$ и может быть эффективно использован только в комплексной антимикробной терапии.

Противоопухолевое действие препаратов кипрея узколистного наиболее выражено и актуально в настоящее время. Исследования на эту тему проводятся во всем мире. В России противоопухолевое действие изучается на самых разных уровнях, от философских предпосылок $[36,80]$ до глубоких научных исследований, показывающих противолучевые и иммунотропные свойства кипрея узколистного. Показатели кле- 
точности костного мозга у белых мышей, получавших экстракт кипрея узколистного, были повышены по сравнению с исходным уровнем на 4-е и 8-е сут. исследования [65]. Имеются исследования, показывающие торможение роста опухолей у мышей и его связь с ханеролом, входящим в химический состав кипрея узколистного [46]. Проведены исследования показывающие влияние экстрактов кипрея узколистного на биосинтез простагландинов и их влияние на индуцированный отек лапы крысы [88]. Показана высокая активность кипрея узколистного при аденокарциноме и лимфосаркоме [47]. Зарубежные исследования противоопухолевых свойств кипрея узколистного нашли свое отражение в конкретных схемах лечения [63].

Существуют исследования, показывающие эффективность экстрактов кипрея узколистного при комплексном лечении рака молочной железы [89].

Лиофилизированный экстракт кипрея мелкоцветкового обладает ингибирующим действием на фермент 5- $\alpha$-редуктаза, который считается ответственным за гиперплазию и последующее развитие онкологии предстательной железы [90-92]. Имеются комплексные исследования, показывающие взаимосвязь антибактериальной, антиоксидантной и противоопухолевой активности препаратов кипрея узколистного [72]. Предпринята попытка выделения отдельных соединений [93] (макроциклический эллаготанин) и оценки влияния полифенолов на пролиферацию клеток нейтральной эндопептитазы [94], отвечающих за противоопухолевую активность кипрея узколистного.

Как видно из представленных данных, кипрей узколистный (Chamerion Angustifolium L.) является очень перспективным растением с большим потенциалом в области комплексного благотворного влияния на организм с ярко выраженным противоопухолевым действием. Но, несмотря на многочисленные исследования, в России кипрей узколистный до сих пор не нашел полноценного применения в области лечения и профилактики онкологических заболеваний. В настоящее время в медицине чрезвычайно востребованы лекарственные препараты, обладающие противоопухолевым действием, так как, по данным ВОЗ, онкологические заболевания являются одной из основных причин заболеваемости и смертности во всем мире - в 2012 г. произошло около 14 млн новых случаев заболевания и 8,2 млн случаев смерти, связанных с раком. Ожидается, что за ближайшие 20 лет число новых случаев заболевания возрастет примерно на 70\%. В 2012 г у мужчин чаще всего диагностировался рак легких, простаты, прямой кишки, желудка и печени. У женщин чаще всего диагностировался рак молочной железы, прямой кишки, легких, шейки матки и желудка.

\section{Заключение}

Из проведенного обзора литературных источников явно следует, что кипрей узколистный - перспективное, с высоким потенциалом биологической активности лекарственное растительное сырье, которое необходимо использовать в официальной фармации и в Российской Федерации, за рубежом это растение используется. Анализ литературных данных свидетельствует о том, что систематических исследований химического состава и биологической активности экстрактивных веществ, содержащихся в биомассе кипрея узколистного, не проводилось, хотя разрозненных данных по составу и биологической активности приведено немало. Особенный интерес вызывают исследования онкопротекторной активности препаратов на основе экстрактивных веществ кипрея узколистного, которых в России практически не проводилось.

Таким образом, поиск и разработка эффективных способов направленного извлечения биологически активных комплексов онкопротекторного действия и изучение их химического состава являются неисследованными и актуальны в настоящее время.

\section{Список литературь}

1. Королёва А.С., Красноборов И.М., Пеньковская Е.Ф. Определитель растений Новосибирской области. Новосибирск, 1973. 368 с.

2. Завражнов В.И., Китаева Р.И., Хмелев К.Ф., Лекарственные растения Центрального Черноземья. Воронеж, 1976. $424 \mathrm{c}$.

3. Дудченко Л.Г., Козьяков А.С., Кривенко В.В. Пряно-ароматические и пряно-вкусовые растения: Справочник. Киев, 1989.304 с.

4. Землинский С.Е. Лекарственные растения СССР. М., 1958. 603 с.

5. Семенов С.Р., Телятьев В.В. Лекарственные растения Восточной Сибири. Иркугск, 1966. 214 с.

6. Орлов В.П., Митина Е.В. Биолого-экологические особенности кипрея узколистного (Chamerion Angustifolium L.) и технологии его заготовки на лекарственные цели // Russian agricultural science review. 2015. №5-1. C. $171-173$. 
7. Dragendorff G. Die Heilpflanzen der verchiedenen Volker und Zeilen. Stuttgart, 1898. 884 p.

8. Кощеев А.К. Дикорастущие съедобные растения в нашем питании. М., 1981. 256 с.

9. Крылов Г.В., Козакова Н.Ф., Лагерь А.А. Растения здоровья. Новосибирск, 1989. 305 с.

10. Черпнин В.Л. Пищевые растения Сибири. Новосибирск, 1987. 192 с.

11. Кравченко И.В., Шепелева Л.Ф., Филимонова М.В., Ганюшкин Л.В. Распределение кислот системы аскорбата в растениях нефтезагрязненных участков Сургутского района // Вестник Томского государственного университета. 2012. №3. С. 110-121.

12. Шапиро Я.С. Некоторые аспекты культивирования кипрея узколистного (Chamerion Angustifolium (L.) Holub, Onagraceae) // Известия Санкт-Петербургского аграрного университета. 2015. №39. С. 29-31.

13. Biotechnology for Medicinal Plants. Chapter 6. Epilobium Sp. Deliu Constantin, Ana Costa and Ta mas Mircea (Willow Herb): Micropropagation and Production of Secondary Metabolites. Springer, 2013. 464 p.

14. Полезные растения Западной Сибири и перспективы их интродукции. Новосибирск, 1972. 380 с.

15. Abdelwahd R., Hakam N., Labhilili M., Udupa S.M. Use of an adsorbent and antioxidants to reduce the effects of leached phenolics in in vitro plantlet regeneration of faba bean // African journal of biotechnology. 2008, Vol. 7(8). Pp. 997-1002.

16. Cristea V., Deliu C., Oltean B., Butiuc-Keul A., Brummer A., Albu C., Radu G.L. Soilless cultures for pharmaceutical use and biodiversity conservation // Acta Horticulturae. 2009. vol. 843. Pp. 157-164.

17. Thiem B., Skrzypczak L., Lamer-Zarawska E. Micropropagation of selected Oenothera species and preliminary studies on their secondary metabolites // Acta Societatis Botanicorum Poloniae. 1999. Vol. 68. Pp. 15-20.

18. Taniguchi S., Imayoshi Y., Hatano T., Yazaki K., Yoshida T. Hydrolysable tannin production in Oenothera tetraptera shoot tissue cultures // Plant Biotechnol. 2002. Vol. 19. Pp. 357-363.

19. Ботанический словарь / под ред. Н. Анненкова. СПб., 1778. С. 327.

20. Валов Р.И., Ханина М.А., Родин А.П. Элементный состав Chamerion Angustifolium (L.) Holub // Сибирское медицинское обозрение. 2010. №5. С. 44-47.

21. Hegnauer R. Chemotaxonomie der Pflanzen. Bd. 1-6. Basel, Stuttgart, 1969; Bd. 5. 506 s; 1966. Bd. 4. 551 s.; 1973. Bd. $6.882 \mathrm{~s}$.

22. Полежаева И.В., Полежаева Н.И., Меняйло Л.Н. Исследование минерального комплекса вегетативной части Chamerion Angustifolium (L.) Holub // Химия растительного сырья. 2005. №4. C. 67-70.

23. Полежаева И.В. Состав эфирного масла кипрея узколистного // Фармация. 2007. №7. С. 7-9.

24. Полежаева И.В. Эколого-географические особенности накопления биологически активных веществ кипрея узколистного (Chamerion Angustifolium (L.) Holub), произрастающего на территории Красноярского края : автореф. дис. ... канд. биол. наук. Красноярск, 2007. 19 с.

25. Полежаева И.В., Полежаева Н.И., Меняйло Л.Н. Аминокислотный и минеральный состав вегетативной части Chamerion Angustifolium (L.) Holub // Химико-фармацевтический журнал. 2007. №3. C. 27-29.

26. Кукина Т.П., Фролова Т.С., Сальникова О.И. Липофильные кислоты Иван-чая узколистного // Химия растительного сырья. 2014. №1. С. 139-146.

27. Максютина Н.П., Середа П.И., Абудеийх 3.Х., Брюзгина Т.С. Изучение жирнокислотного состава липидного комплекса кипрея узколистного (Иван-чая) // Фітотерапія. Часопис. 2010. №4. С. 93-95.

28. Guil-Guerrero J.L., García Maroto F.F., Giménez Giménez A. Fatty acid profiles from fortynine plant species that are potential new sources of c-linolenic acid // JAOCS. 2001. Vol. 78. Pp. 677-684.

29. Пашенных О.К. Лесные пищевые травянистые растения Средней Сибири : дис. ... канд. биол. наук. Красноярск, 1989. $241 \mathrm{c.}$

30. Полежаева И.В. Изучение экстрактов наземной части Chamerion Angustifolium (L.) Holub // Вестник Красноярского государственного аграрного университета. 2007. №3. С. 91-94.

31. Полежаева И.В., Полежаева Н.И., Меняйло Л.Н., Павленко Н.И., Левданский В.А. Изучение экстрактивных веществ Chamerion Angustifolium (L.) Holub // Химия растительного сырья. 2005. №1. C. 25-29.

32. Валов Р.И. Фармакогностическое исследование надземной части Chamerion Angustifolium (L.) Scop. : автореф. дис. ... канд. фарм. наук. Улан-Удэ, 2012. 22 с.

33. Полежаева И.В., Полежаева Н.И., Левданский В.А. Сравнительное исследование химического состава кипрея узколистного // Вестник КГУ. Естественные науки. 2005. №2. С. 130-133.

34. Ткабладзе Ц.П. Связь между наполнением дубильных веществ и их содержанием в некоторых таниноносных растениях Грузии. Тбилиси, 1961. 88 с.

35. Минаева В.Г. Лекарственные растения Сибири. Новосибирск, 1991. 431 с.

36. Переверзева И.С. Изучение перспектив разработки современного препарата на основе кипрея узколистного, произрастающего в Самарской области // Молодые ученые XXI века - от идеи к практике: материалы докл. междунар. науч.-практ. конф. Самара, 2015. С. 175.

37. Захаров А.М., Боряев К.И. Поиски флавоноидноносных растений во флоре некоторых районов Киргизии и Казахстана // Растительные ресурсы. 1966. Т. 2, вып. 1. С. 14-27.

38. Arredondo M.F., Blasina F., Echeverry C., Morquio A., Ferreiora M., Abin-Carriquiry J.A., Lafon L., Dajas F. Cytoprotection by Achyrocline satureioides (Lam) D.C. and some of its main flavonoids against oxidative stress // Ethnopharmac. 2004. Vol. 91. Pp.13-20.

39. Stalikas K. Extraction, separation, and detection methods for phenolic acids and flavonoids // Sep. Sci. 2007. Vol. 30. Pp. 3268-3295. 
40. Averett J.E., Kerr B., Raven P.H. Flavonoids of Onagraceae: Epilobium sect. Epilobium // Amer. J. Bot. 1978. Vol. 65. Pp. 567-570.

41. Муравьёва Д.А., Баньковский А.И. Исследование растений, применяемых в народной медицине, на содержание аскорбиновой кислоты // Труды ВНИИ лекарственных и ароматических растений. 1949. Вып. 9. С. 39-118.

42. Романович Е.А. Лекарственные растения Северной Осетии и содержание в них аскорбиновой кислоты. Орджоникидзе, 1969. 280 с.

43. Турова А.Д., Сапожникова Э.Н. Лекарственные растения СССР и их применение. М., 1984. С. $303-304$.

44. Amer J., Hussein S.A.M., Marzour M.S., Merfort I., Linscheid M., Nawwar M.A.M. Polyphenolic metabolites of Epilobium hirsutum // Barakat HH. 1997. Vol. 66. Pp. 1151-1155.

45. Liu Y., Wang C., Han Q., Yu B., Ding G. Study on chemical constituents of Chamaenerion angustifolium II. Tannins and related polyphenolic compounds // Chin. Trad. Herb. Drugs. 2003. Vol. 34. Pp. 967-969.

46. Сыркин А.Б., Коняева О.И. Фармацевтические исследования некоторых новых противоопухолевых средств // Химико-фармацевтический журнал. 1984. №10. С. 1172-1180.

47. Рабинович А.М. Фитотерапия против рака // Экология и жизнь. 2001. №5. С. 78-81.

48. Hunecr S. Triterpenes unsaponifiable neutral constituents from Chamaeneration Angustifolium and Epilobium obscurum // Phytochemistry. 1967. Vol. 6, №8. Pp. 1149-1150.

49. Barakat H.H., Hussein S.A.M., Marzour M.S., Merfort I., Linscheid M., Nawwar M.A.M. Polyphenolic metabolites of Epilobium hirsutum // Phytochem. 1997. Vol. 46. Pp. 935-941.

50. Glen A.T., Lawrie W., McLean J., El-Garby Y.M. Triterpenoid constituents of rosebay willow-herb // J. Chem. Soc. C. Org. chem. 1967. Vol. 26. Pp. 510-515.

51. Bale-Smilh E.C. The phenolie consliluents of plants and their taxonomie sidnificance Bol. J. Linn. // J. Microbios Soc. 1962. Vol. 58, N371. Pp. 95-173.

52. Slacanin I., Marston A., Hostettmann K., Delabays N., Darbellay C. Isolation and determination of flavonol glycosides from Epilobium species // J. Chromatogr. 1991. Vol. 557. Pp. 391-398.

53. Ducrey B., Wolfender J.L., Marston A., Hostettmann K. Analysis of flavonol glycosides of thirteen Epilobium species (Onagraceae) by LC-UV and thermospray LC-MS // Phytochemistry. 1995. Vol. 38. Pp. 129-137.

54. А.с. 396040 СССР. Способ получения фитогемагглютинина, обладающего противоопухолевой активностью / Е.Ч. Пухальская, М.Ф. Петрова, П.Н. Кибальчич, С.И. Денисова, Г.Н. Платонова, И.О. Черняховская, Т.А. Алиева. 1974. БИ. №7. С. 27.

55. Hiermann A., Bucar F. Studies of Epilobium angustifolium extracts on growth of accessory sexual organs in rats // J. Ethnopharmacol. 1997. Vol. 55. Рp. 179-183.

56. Пекшибаев М.И., Золан И.И. Кипрей // Кожевенно-обувная промышленность. 1938. №4. С. $27-28$.

57. Дорофеев Н.С. Ресурсы медоносных растений Мордовской АССР // Растительные ресурсы. 1980. Т. 16, вып. 2. C. $167-176$.

58. Марнова Л.Г. Таниноносы восточной части центрального Тянь-Шаня // Флора СССР. 1952. Т. 18. С. 148.

59. Роллов А.Х. Дикорастущие растения Кавказа их распространение, свойства и применение. Тифлис, 1908. 599 с.

60. Tyler V.E. Some recent advances in herbal medicine // International Journal of Pharmaceutics. 1986. Vol. 7. Pp. $203-207$.

61. Nowak R., Krzaczek T. Pharmacognostical research involving herbs of Epilobium agustifolium L. and Epilobium parviflorum Schreb // Herba Polonica. 1998b. Vol. 1. Pp. 5-10.

62. Hevesi Tóth B. Phytochemical and in vitro biological evaluation of potentially active compounds in Epilobium species. Thesis of doctoral (Ph.D.) dissertation. Semmelweis University, Department of Pharmacognosy. Budapest, 2009. Pp. 2-14.

63. Bisset N.G., Wichtl M. Herbal drugs and phytopharmaceuticals. A handbook for practice on a scientific basis. Stuttgart, CRC Press. 1994. С. 708.

64. Турова А.Д. Лекарственные растения СССР и их применение. М., 1974. 424 с.

65. Суркова О.В. Противоопухолевые и иммунотропные свойства Звездчатки средней (Stellaria Media) и кипрея узколистного (Chamaenerion Angustifolium) : автореф. дис. ... канд. биол. наук. Покров, 2009. 24 с.

66. Викторов В.К., Корсун В.Ф. Уникальные лечебные свойства сорняков. М., 2010. 270 с.

67. Zhang J., Li L., Kim S.H., Hagerman A.E., Junxuan Lü.J. Anti-cancer, anti-diabetic and other pharmacologic and biological activities of penta-galloyl-glucose // Pharm. Res. 2009. Vol. 26. Pp. 2066-2080.

68. Hoppe H.A. Drogen Kunde. Berlin, New-York, 1975. $1311 \mathrm{s.}$

69. Assessment report on Epilobium Angustifolium L. and/or Epilobium parviflorum Schreb. Committee on Herbal Medicinal Products (HMPC) EMA/HMPC/712510/2014. Pp. 1-20.

70. Муллагулов Р.Т., Козлов В.Н., Пономарева Л.Ф. Изучение антиоксидантной активности лекарственных трав методом хемилюминесценции в опытах in vitro // Вестник Волжского университета им. В.Н. Татищева. 2012. №1. C. 231-234.

71. Hevesi T.B., Blazics B., Kéry Á. Polyphenol composition and antioxidant capacity of Epilobium species // Journal of Pharmaceutical and Biomedical Analysis. 2009. Vol. 49. Pp. 26-31.

72. Steenkamp V., Gouws M.C., Gulumian M., Elgorashi E.E., van Staden J. Studies on antibacterial, anti-inflammatory and antioxidant activity of herbal remedies used in the treatment of benign prostatic hyperplasia and prostatitis // J. Ethnopharmacol. 2006. Vol. 103. Pp. 71-75.

73. Hevesi T.B., Blazics B., Kéry Á. Polyphenol composition and antioxidant capacity of Epilobium species // Journal of Pharmaceutical and Biomedical Analysis. 2009. Vol. 49. Pp. 26-31. 
74. Shikov A.N., Poltanov E.A., Dorman H.J., Makarov V.G., Tikhonov V.P., Hiltunen R. Chemical composition and in vitro antioxidant evaluation of commercial water-soluble willow herb (Epilobium angustifolium L.) extracts // Journal Agric Food Chemistry. 2006. Vol. 54. Pp. 3617-3624.

75. Kiss A.K., Bazylko A., Filipek A., Granica S., Jaszewska E., Kiarszus U., Kos'mider A., Piwowarski J. Oenothein B's contribution to the anti-inflammatory and antioxidant activity of Epilobium sp // Phytomed. 2010. Vol. 18 (7) Pp. 557-560.

76. Кукина Т.П., Синицына О.И., Фролова Т.С. Анализ генотоксических и антимутагенных свойств тритерпеноидов кипрея узколистного // Проблемы современной науки. 2011. №1. С. 3-16.

77. Rivera F., Gervaz E., Sere C., Dajas F. Toxicological studies of the aqueous extract from Achyrocline satureioides (Lam.) DC (Marcela) // Journal of Ethnopharmacology. 2004. Vol. 95, N2-3. Pp. 359-362.

78. Цыдендамбаев П.Б., Хышиктуев Б.С., Николаев С.М. Биологические эффекты флавоноидов // Бюллетень ВСНЦ СО РАМН. 2006. №6. С. 229-233.

79. Nicrett L.G. Antimicrobia activity of vascular plants // Econ. Bot. 1959. Vol. 14. N4. Pp. 281-318.

80. Нугманова А.И., Галкина Л.А., Багаева Т.В. Гидролитические ферменты Иван-чая (Chamerion Angustifolium) // Биотехнология. Взгляд в будущее: материалы III Междунар. науч. интернет-конф. 2014. С. 26-28.

81. Ivancheva S., Manolova N., Serkedjieva J., Dimov V., Ivanovska N. Polyphenols from Bulgarian medicinal plants with anti-infectious activity // Basic Life Sci. 1992. Vol. 59. Pp. 717-728.

82. Vitalonea A., McCollb J., Thomeb D., Lucio G., Titaa C.B. Characterization of the Effect of Epilobium Extracts on Human Cell Proliferation // Karger. 2003. Vol. 69. N2. Pp 79-87.

83. Hiermann A., Reidlinger M., Juan H., Samez W. Isolierung des antiphlogistischen Wirkprinzips von Epilobium angustifolium (isolation of the antiphlogistic principle from Epilobium angustifolium) // Planta Med. 1991. Vol. 57. Pp. 357-360.

84. Золотницкая С.Я. Новые алкалоидоносные растения флоры Армении // Известия АН Арм ССР. 1954. Т. 7, №5. C. 27-29.

85. Fukuchi K., Sakagami H., Okuda T. et al. Inhibition of herpes simplex virus infection by tannins and related compounds // Antiviral. Res. 1989. Vol. 11. Pp. 285-298.

86. Bartfay W.J., Bartfay E., Green-Johnson J. Gram-negative and gram-positive antibacterial properties of the whole plant extract of willow herb (Epilobium angustifolium) // Biol. Res. Nurs. 2012. Vol. 14 (1). Pp. 87-90.

87. Battinelli L., Tita B., Evandri M.G., Mazzanti G. Antimicrobial activity of Epilobium spp. Extracts // II Farmaco. 2001. Vol. 56. Pp. 345-348.

88. Hiermann A., Juan H., Sametz W. Influence of Epilobium extracts on prostaglandin biosynthesis and carrageenin induced oedema of the rat paw // J. Ethnopharmacol. 1986. Vol. 17. Pp. 161-169.

89. Aoki K., Maruta H., Uchiumi F., Hatano T., Yoshida T., Tanuma S. A macrocircular ellagitannin, oenothein B, suppresses mouse mammary tumor gene expression via inhibition of poly(ADP-ribose) glycohydrolase // Biochem. Biophys. Res. Commun. 1995. Vol. 210. Pp. 329-337.

90. Ducrey B., Marston A., Gohring S., Hartmann R.W., Hostettmann K. Inhibition of 5 areductase and aromatase by the ellagitannins oenothein A and oenothein B from Epilobium species // Planta. Med. 1997. Vol. 63. Pp. 111-114.

91. Lesuisse D., Berjonneau J., Ciot C. et al. Determination of oenothein B as the active 5-alphareductase-inhibiting principle of the folk medicine Epilobium parviflorum // J. Nat. Prod. 1996. Vol. 59. Pp. 490-492.

92. Vitalone A., Bordi F., Baldazzi C., Mazzanti G., Saso L., Tita B. Anti-proliferative effect on a prostatic epithelial cell line (PZ-HPV-7) by Epilobium angustifolium L // Farmaco. 2002. Vol. 56. Pp. 483-489.

93. Miyamoto K., Nomura M., Sasakura M. et al. Antitumor activity of oenothein B, a unique macrocyclic ellagitannin // Jpn. J. Cancer. Res. 1993c. Vol. 84. Pp. 99-103.

94. Kiss A., Kowalski J., Melzig M.F. Effect of Epilobium angustifolium L. extracts and polyphenols on cell proliferation and neutral endopeptidase activity in selected cell lines // Pharmazie. 2006a. Vol. 61. Pp. 66-69.

Поступило в редакцию 18 октября 2016 г.

После переработки 7 ноября 2016 г. 
Tsarev V.N. ${ }^{1,2 *}$, Bazarnova N.G. ${ }^{l}$, Dubenskii M.M. ${ }^{2}$ CHAMERION ANGUSTIFOLIUM L. CHEMICAL COMPOSITION, BIOLOGICAL ACTIVITY (REVIEWS)

${ }^{\text {I} A l t a i}$ State University, Lenina av., 61, Barnaul,656049 (Russia),e-mail: tsarewvn@gmail.com

${ }^{2}$ LLC "Laboratory grinap", Krupskoi st., 145, Barnaul, 656031 (Russia)

The report examines the Chamerion Angustifolium Onagraceae, the place of its natural habitat, botanical and morphological description of the pharmacological properties and chemical composition.

The chemical composition of fireweed narrow-leaved enough studied as element and component, but, despite this, has not yet revealed the relationship of biologically active complexes with pharmacological action, not developed any filesystem project is not created a single drug with a biologically complex active substances extracted from fireweed narrow-leaved.

There is speculation about the mechanism of antitumor action of fireweed narrow-leaved and melkotsvetnogo, but there is no fixed chemical composition depending on the action.

Survey data serve as a basis for further study of the chemical composition of fireweed narrow-leaved, to determine the chemical composition of the relationship and his actions as onkoprotektor. Just aim to develop a methodology for the extraction of dry and fresh feed (grass fireweed narrow-leaved) with a maximum biological activity. methods.

Keywords: Chamerion Angustifolium Onagraceae, extractives, chemical composition, biological activity, extraction

\section{References}

1. Koroleva A.S., Krasnoborov I.M., Pen'kovskaia E.F. Opredelitel' rastenii Novosibirskoi oblasti. [The determinant of plants of Novosibirsk Region]. Novosibirsk, 1973, 368 p. (in Russ.).

2. Zavrazhnov V.I., Kitaeva R.I., Khmelev K.F. Lekarstvennye rasteniia Tsentral'nogo Chernozem'ia. [Medicinal Plants of the Central Chernozem]. Voronezh, 1976, 424 p. (in Russ.).

3. Dudchenko L.G., Koz'iakov A.S., Krivenko V.V. Priano-aromaticheskie i priano-vkusovye rasteniia: Spravochnik. [Spicy, aromatic and spicy taste Plants: A Handbook]. Kiev, 1989, 304 p. (in Russ.).

4. Zemlinskii S.E. Lekarstvennye rasteniia SSSR. [Medicinal plants of the USSR]. 3 ed. Moscow, 1958, 603 p. (in Russ.).

5. Semenov S.R., Teliat'ev V.V. Lekarstvennye rasteniia Vostochnoi Sibiri. [Medicinal plants of East Siberia]. Irkutsk, 1966, 214 p. (in Russ.).

6. Orlov V.P., Mitina E.V. Russian agricultural science review, 2015, no. 5-1, pp. 171-173. (in Russ.).

7. Dragendorff G. Die Heilpflanzen der verchiedenen Volker und Zeilen. Stuttgart, 1898. 884 p.

8. Koshcheev A.K. Dikorastushchie s"edobnye rasteniia v nashem pitanii. [Wild edible plants in our diet]. Moscow, 1981, 256 p. (in Russ.).

9. Krylov G.V., Kozakova N.F., Lager' A.A. Rasteniia zdorov'ia. [Health Plants]. Novosibirsk, 1989, 305 p. (in Russ.).

10. Cherpnin V.L. Pishchevye rasteniia Sibiri. [Edible Plants of Siberia]. Novosibirsk, 1987, 192 p. (in Russ.).

11. Kravchenko I.V., Shepeleva L.F., Filimonova M.V., Ganiushkin L.V. Vestnik Tomskogo gosudarstvennogo universiteta, 2012, no. 3, pp. 110-121. (in Russ.).

12. Shapiro Ia.S. Izvestiia Sankt-Peterburgskogo gosudarstvennogo agrarnogo universiteta, 2015, no. 39, pp. 29-31. (in Russ.).

13. Biotechnology for Medicinal Plants. Chapter 6. Epilobium Sp. Deliu Constantin, Ana Costa and Ta mas Mircea (Willow Herb): Micropropagation and Production of Secondary Metabolites. Springer, 2013. 464 p.

14. Poleznye rasteniia Zapadnoi Sibiri i perspektivy ikh introduktsii. [Useful Plants of West Siberia and the prospects for their introduction]. Novosibirsk, 1972, 380 p. (in Russ.).

15. Abdelwahd R., Hakam N., Labhilili M., Udupa S.M. African journal of biotechnology, 2008, vol. 7(8), pp. 997-1002.

16. Cristea V., Deliu C., Oltean B., Butiuc-Keul A., Brummer A., Albu C., Radu G.L. Acta Horticulturae, 2009, vol. 843, pp. $157-164$.

17. Thiem B., Skrzypczak L., Lamer-Zarawska E. Acta Societatis Botanicorum Poloniae, 1999, vol. 68, pp. 15-20.

18. Taniguchi S., Imayoshi Y., Hatano T., Yazaki K., Yoshida T. Plant Biotechnol., 2002, vol. 19, pp. 357-363.

19. Botanicheskii slovar'. [Botanical Dictionary]. Ed. N. Annenkov. St. Petersburg, 1778, 327 p. (in Russ.).

20. Valov R.I., Khanina M.A., Rodin A.P. Sibirskoe meditsinskoe obozrenie, 2010, no. 5, pp. 44-47. (in Russ.).

21. Hegnauer R. Chemotaxonomie der Pflanzen. Bd. 1-6. Basel, Stuttgart, 1969; Bd. 5. 506 s; 1966. Bd. 4. 551 s.; 1973. Bd. 6. 882 s. (in German).

22. Polezhaeva I.V., Polezhaeva N.I., Meniailo L.N. Khimiia rastitel'nogo syr'ia, 2005, no. 4, pp. 67-70. (in Russ.).

23. Polezhaeva I.V. Farmatsiia, 2007, no. 7, pp. 7-9. (in Russ.).

24. Polezhaeva I.V. Ekologo-geograficheskie osobennosti nakopleniia biologicheski aktivnykh veshchestv Kipreia uzkolistnogo (Chamerion Angustifolium (L.) Holub), proizrastaiushchego na territorii Krasnoiarskogo kraia : avtoref. dis. ... kand. biol. nauk. [Ecological and geographical features of accumulation of biologically active substances fireweed narrow-leaved (Chamerion Angustifolium (L.) Holub), which grows in the Krasnoyarsk Territory: the dissertation author's candidate of biological sciences]. Krasnoyarsk, 2007, 19 p. (in Russ.).

25. Polezhaeva I.V., Polezhaeva N.I., Meniailo L.N. Khimiko-farmatsevticheskii zhurnal, 2007, no. 3, pp. 27-29. (in Russ.).

26. Kukina T.P., Frolova T.S., Sal'nikova O.I. Khimiia rastitel'nogo syr'ia, 2014, no. 1, pp. 139-146. (in Russ.).

27. Maksiutina N.P., Sereda P.I., Abudeiikh Z.Kh., Briuzgina T.S. Fitoterapija. Chasopys, 2010, no. 4, pp. 93-95. (in Russ.).

28. Guil-Guerrero J.L., García Maroto F.F., Giménez Giménez A. JAOCS, 2001, vol. 78, pp. 677-684.

\footnotetext{
${ }^{*}$ Corresponding author.
} 
29. Pashennykh O.K. Lesnye pishchevye travianistye rasteniia Srednei Sibiri : dis. ... kand. biol. nauk. [Wild edible herbaceous plants of Middle Siberia: the dissertation candidate of biological sciences]. Krasnoyarsk, 1989, 241 p. (in Russ.).

30. Polezhaeva I.V. Vestnik Krasnoiarskogo gosudarstvennogo agrarnogo universiteta, 2007, no. 3, pp. 91-94. (in Russ.).

31. Polezhaeva I.V., Polezhaeva N.I., Meniailo L.N., Pavlenko N.I., Levdanskii V.A. Khimiia rastitel'nogo syr'ia, 2005, no. 1, pp. 25-29. (in Russ.).

32. Valov R.I. Farmakognosticheskoe issledovanie nadzemnoi chasti Chamerion Angustifolium (L.) Scop. : avtoref. dis. ... kand. farm. nauk. [Farmakognostichesky study of the aerial part Chamerion Angustifolium (L.) Scop. : Dissertation of the candidate of pharmaceutical sciences]. Ulan-Ude, 2012, 22 p. (in Russ.).

33. Polezhaeva I.V., Polezhaeva N.I., Levdanskii V.A. Vestnik KGU. Estestvennye nauki, 2005, no. 2, pp. 130-133. (in Russ.).

34. Tkabladze Ts.P. Sviaz' mezhdu napolneniem dubil'nykh veshchestv i ikh soderzhaniem v nekotorykh taninonosnykh rasteniiakh Gruzii. [The relationship between the content of tannins and their contents in some plants taninonosnyh Georgia]. Tbilisi, 1961, 88 p. (in Russ.).

35. Minaeva V.G. Lekarstvennye rasteniia Sibiri. [Medicinal Plants of Siberia]. Novosibirsk, 1991, 431 p. (in Russ.).

36. Pereverzeva I.S. Molodye uchenye XXI veka - ot idei $k$ praktike: materialy dokl. mezhdunar. nauch.-prakt. konf. [Young scientists of the XXI century - from idea to practice: Proceedings of the international scientific-practical conference]. Samara. 2015, pp. 175. (in Russ.).

37. Zakharov A.M., Boriaev K.I. Rastitel'nye resursy, 1966, vol. 2, no. 1, pp. 14-27. (in Russ.).

38. Arredondo M.F., Blasina F., Echeverry C., Morquio A., Ferreiora M., Abin-Carriquiry J.A., Lafon L., Dajas F. Ethnopharmac, 2004, vol. 91, pp.13-20.

39. Stalikas K. Sep. Sci., 2007, vol. 30, pp. 3268-3295.

40. Averett J.E., Kerr B., Raven P.H. Amer. J. Bot., 1978, vol. 65, pp. 567-570.

41. Murav'eva D.A., Ban'kovskii A.I. Trudy VNII lekarstvennykh i aromaticheskikh rastenii. [Proceedings of the Institute of Medicinal and Aromatic Plants]. 1949, no. 9, pp. 39-118. (in Russ.).

42. Romanovich E.A. Lekarstvennye rasteniia Severnoi Osetii i soderzhanie v nikh askorbinovoi kisloty. [Medicinal plants of North Ossetia and the content of ascorbic acid]. Ordzhonikidze, 1969, 280 p. (in Russ.).

43. Turova A.D., Sapozhnikova E.N. Lekarstvennye rasteniia SSSR $i$ ikh primenenie. [Medicinal plants of the USSR and their application]. Moscow, 1984. pp. 303-304. (in Russ.).

44. Amer J., Hussein S.A.M., Marzour M.S., Merfort I., Linscheid M., Nawwar M.A.M. Barakat HH, 1997, vol. 66, pp. 1151-1155.

45. Liu Y., Wang C., Han Q., Yu B., Ding G. Chin. Trad. Herb. Drugs., 2003, vol. 34, pp. 967-969.

46. Syrkin A.B., Koniaeva O.I. Khimiko-farmatsevticheskii zhurnal, 1984, no. 10, pp. 1172-1180. (in Russ.).

47. Rabinovich A.M. Ekologiia i zhizn', 2001, no. 5, pp. 78-81. (in Russ.).

48. Hunecr S. Phytochemistry, 1967, vol. 6, no. 8, pp. 1149-1150.

49. Barakat H.H., Hussein S.A.M., Marzour M.S., Merfort I., Linscheid M., Nawwar M.A.M. Phytochem., 1997, vol. 46, pp. 935-941.

50. Glen A.T., Lawrie W., McLean J., El-Garby Y.M. J. Chem. Soc. C. Org. chem., 1967, vol. 26, pp. 510-515.

51. Bale-Smilh E.C. J. Microbios Soc., 1962, vol. 58, no. 371, pp. 95-173.

52. Slacanin I., Marston A., Hostettmann K., Delabays N., Darbellay C. J. Chromatogr., 1991, vol. 557, pp. 391-398.

53. Ducrey B., Wolfender J.L., Marston A., Hostettmann K. Phytochemistry, 1995, vol. 38, pp. 129-137.

54. Certificate of authorship 396040 USSR. 1974. (in Russ.).

55. Hiermann A., Bucar F. J. Ethnopharmacol., 1997, vol. 55, pp. 179-183.

56. Pekshibaev M.I., Zolan I.I. Kozhevenno-obuvnaia promyshlennost', 1938, no. 4, pp. 27-28. (in Russ.).

57. Dorofeev N.S. Rastitel'nye resursy, 1980, vol. 16, no. 2, pp. 167-176. (in Russ.).

58. Marnova L.G. Flora SSSR. [Flora of the USSR]. 1952, vol. 18, pp. 148. (in Russ.).

59. Rollov A.Kh. Dikorastushchie rasteniia Kavkaza ikh rasprostranenie, svoistva i primenenie. [Wild Plants of the Caucasus their distribution, properties and applications]. Tiflis, 1908, 599 p. (in Russ.).

60. Tyler V.E. International Journal of Pharmaceutics, 1986, vol. 7, pp. 203-207.

61. Nowak R., Krzaczek T. Herba Polonica, 1998b, vol. 1, pp. 5-10.

62. Hevesi Tóth B. Phytochemical and in vitro biological evaluation of potentially active compounds in Epilobium species. Thesis of doctoral (Ph.D.) dissertation. Semmelweis University, Department of Pharmacognosy. Budapest, 2009. pp. 2-14.

63. Bisset N.G., Wichtl M. Herbal drugs and phytopharmaceuticals. A handbook for practice on a scientific basis. Stuttgart, CRC Press. 1994. C. 708.

64. Turova A.D. Lekarstvennye rasteniia SSSR i ikh primenenie. [Medicinal plants of the USSR and their application]. Moscow, 1974, 424 p. (in Russ.).

65. Surkova O.V. Protivoopukholevye i immunotropnye svoistva Zvezdchatki srednei (Stellaria Media) $i$ Kipreia uzkolistnogo (Chamaenerion Angustifolium) : avtoref. dis. ... kand. biol. nauk. [Antitumor and immunotropnye properties Stellaria Media and Chamaenerion Angustifolium : the dissertation author's candidate of biological sciences]. Pokrov, 2009, 24 p. (in Russ.).

66. Viktorov V.K., Korsun V.F. Unikal'nye lechebnye svoistva sorniakov. [Unique therapeutic properties of weeds]. Moscow, 2010, 270 p. (in Russ.).

67. Zhang J., Li L., Kim S.H., Hagerman A.E., Junxuan Lü.J. Pharm. Res., 2009, vol. 26, pp. 2066-2080. 
68. Hoppe H.A. Drogen Kunde. Berlin, New-York, 1975. 1311 p.

69. Assessment report on Epilobium Angustifolium L. and/or Epilobium parviflorum Schreb. Committee on Herbal Medicinal Products (HMPC) EMA/HMPC/712510/2014. Pp. 1-20.

70. Mullagulov R.T., Kozlov V.N., Ponomareva L.F. Vestnik Volzhskogo universiteta im. V.N. Tatishcheva, 2012, no. 1, pp. 231-234. (in Russ.).

71. Hevesi T.B., Blazics B., Kéry Á. Journal of Pharmaceutical and Biomedical Analysis, 2009, vol. 49, pp. $26-31$.

72. Steenkamp V., Gouws M.C., Gulumian M., Elgorashi E.E., van Staden J. J. Ethnopharmacol., 2006, vol. 103, pp. 71-75.

73. Hevesi T.B., Blazics B., Kéry Á. Journal of Pharmaceutical and Biomedical Analysis, 2009, vol. 49, pp. $26-31$.

74. Shikov A.N., Poltanov E.A., Dorman H.J., Makarov V.G., Tikhonov V.P., Hiltunen R. Journal Agric Food Chemistry, 2006, vol. 54, pp. 3617-3624.

75. Kiss A.K., Bazylko A., Filipek A., Granica S., Jaszewska E., Kiarszus U., Kos'mider A., Piwowarski J. Phytomed., 2010, vol. 18(7), pp.557-560

76. Kukina T.P., Sinitsyna O.I., Frolova T.S. Problemy sovremennoi nauki, 2011, no. 1, pp. 3-16. (in Russ.).

77. Rivera F., Gervaz E., Sere C., Dajas F. Journal of Ethnopharmacology, 2004, vol. 95, no. 2-3, pp. 359-362.

78. Tsydendambaev P.B., Khyshiktuev B.S., Nikolaev S.M. Biulleten' Vostochno-Sibirskogo nauchnogo tsentra Sibirskogo otdeleniia Rossiiskoi Akademii meditsinskikh nauk, 2006, no. 6, pp. 229-233. (in Russ.).

79. Nicrett L.G. Econ. Bot., 1959, vol. 14, no. 4, pp. 281-318.

80. Nugmanova A.I., Galkina L.A., Bagaeva T.V. Biotekhnologiia. Vzgliad v budushchee: materialy III mezhdunar. nauch. internet-konf. [Biotechnology. Looking to the future: materials III international scientific Internet conference]. 2014, pp. 26-28. (in Russ.).

81. Ivancheva S., Manolova N., Serkedjieva J., Dimov V., Ivanovska N. Basic Life Sci., 1992, vol. 59, pp. 717-728.

82. Vitalonea A., McCollb J., Thomeb D., Lucio G., Titaa C.B. Karger, 2003, vol. 69, no. 2, pp 79-87.

83. Hiermann A., Reidlinger M., Juan H., Samez W. Planta Med., 1991, vol. 57, pp. 357-360.

84. Zolotnitskaia S.Ia. Izvestiia Akademii nauk Armianskoi SSR, 1954, vol. 7, no. 5, pp. 27-29. (in Russ.).

85. Fukuchi K., Sakagami H., Okuda T. et al. Antiviral. Res., 1989, vol. 11, pp. 285-298.

86. Bartfay W.J., Bartfay E., Green-Johnson J. Biol. Res. Nurs., 2012, vol. 14(1), pp. 87-90.

87. Battinelli L., Tita B., Evandri M.G., Mazzanti G. II Farmaco., 2001, vol. 56, pp. 345-348.

88. Hiermann A., Juan H., Sametz W. J. Ethnopharmacol., 1986, vol. 17, pp. 161-169.

89. Aoki K., Maruta H., Uchiumi F., Hatano T., Yoshida T., Tanuma S. Biochem. Biophys. Res. Commun., 1995, vol. 210, pp. 329-337.

90. Ducrey B., Marston A., Gohring S., Hartmann R.W., Hostettmann K. Planta. Med., 1997, vol. 63, pp. 111-114.

91. Lesuisse D., Berjonneau J., Ciot C. et al. J. Nat. Prod., 1996, vol. 59, pp. 490-492.

92. Vitalone A., Bordi F., Baldazzi C., Mazzanti G., Saso L., Tita B. Farmaco, 2002, vol. 56, pp. 483-489.

93. Miyamoto K., Nomura M., Sasakura M. et al. Jpn. J. Cancer. Res., 1993c, vol. 84, pp. 99-103.

94. Kiss A., Kowalski J., Melzig M.F. Pharmazie, 2006a, vol. 61, pp. 66-69. 